\title{
RECENT EXTENSIONS IN THE USE OF COMMERCIAL LETTERS OF CREDIT
}

THE commercial letter of credit-long familiar in banking circles as a means of providing for the payment of goods-has adopted a new look. ${ }^{1}$ Influenced by the simplicity, inexpensiveness and feasibility of the letter of credit mechanism, ${ }^{2}$ contracting parties now utilize the instrument as security against a failure of performance, a demand traditionally fulfilled by placing funds in escrow or posting a bond. In contrast to the orthodox use of the instrument, where the parties anticipate that the letter of credit will be the means of paying for a sale, the beneficiary of the "new" letter of credit will collect from the bank only in the event of a contingency which the parties do not expect will occur. While such an arrangement is the most practical method of handling many transactions, it also raises significant mechanical and legal problems, both for the banks and for the contracting parties.

1. Information on the new use of letters of credit was obtained in the course of several interviews with commercial bankers in New York and San Francisco (hereinafter cited as INTERVIEws) who have helped to develop the technique. One banker estimated that of the commercial credits of all descriptions issued by his bank in 1956, some $10 \%$ were of this nature. The fact situations to be considered in text are samples of actual transactions made by banks engaged in international trade. The Yale Lazo Journal acknowledges with gratitude the cooperation of these several banks in making available such information.

2. Evidence of the pliability inherent in the instrument is the fact that legal writers have been able to describe its operation in terms of half a dozen different concepts. Demogue, Le Crédit Documentaire en Droit Anglais 147-52 (1934); Hershey, Letters of Credit, 32 Harv. L. Rev. 1, 3 (1918). See Llewellyn, Introduction, in FinkELSTEIN, Legal Aspects of Commerctal Letrers of Credit xxvii-xxviii (1930) (hereinafter cited as Finkelstein). See also Gutteridge \& Megram, The Law of Bankers' Comarercial CReDits 14-26 (1955) (hereinafter cited as GutTeridge \& Megran); Trimble, The Law Merchant and the Letter of Credit, 61 HARv. L. Rev. 981 (1948); Thayer, Irrevocablc Credits in International Commerce: Their Legal Nature, 36 CoLuns. L. Rev. 1031 (1936).

Less concerned with the legal theories by which the parties may or may not be liable, the banking community has recognized a wide variety of forms of letters of credit, each of which creates different legal obligations, e.g., revocable and irrevocable credits, confirmed and unconfirmed, negotiation and straight. RosENTHAL, TECHNIQUES OF INTERNAtional Trade 340-48 (1950); Ward \& Harfield, Bank Credits and Acceptances 27-32 (3d ed. 1948) (hereinafter cited as Ward \& HarfielD). See also Dants, The LAw RElating to Commerctal LetTers of Credit $23-41$ (2d ed. 1954) (hereinafter cited as Davis); Thayer, Irrevocable Credits in International Commerce: Their Legal Effects, 37 Colum. L. REv. 1326 (1937). While most of the credits which will be considered here are irrevocable, confirmed and straight, the distinctions are of but incidental importance with the possible exception of the "clean"- "documentary" dichotomy. See note 34 infra and accompanying text.

The "travelers' letter of credit" is a different animal, retaining the family name for geneological reasons but otherwise unrelated to the present context. See Hershey, supra at $4-9$. 


\section{The Letter of Credit as Protection for a Performer}

Commercial letters of credit have traditionally been used to provide payment for international sales. ${ }^{3}$ The buyer requests his bank to open a letter of credit naming his foreign supplier as beneficiary. ${ }^{4}$ The seller obtains immediate payment for the goods shipped abroad when he presents specified shipping documents to the local bank which has confirmed the letter of credit. The confirming bank is obligated to pay upon presentation of conforming documents, irrespective of the seller's compliance with other terms of the underlying sales contract. ${ }^{\circ}$ The confirming bank is then entitled to reimbursement from the bank issuing the letter of credit, ${ }^{7}$ which in turn collects from the buyer. ${ }^{8}$

3. Von Klemperer, Present Foreign Payment Practices in the United States, 2 INTERnational Monetary Fund, Staff Papers 199, 201 (1951-52) ; Organization for European Economirc Cooperation, The OEEC Bankers' Misston to the U.S.A., TeChnicat Assistance Mission No. 31, Report on Uniform Rules and Practice Relating to Commanctal Letrers of CREDIT, Annex V (Sept. 1951). Letters of credit were first issued in any quantity in this country following World War I. RosenTHAL, op. cit. supra note 2 , at 341-42. But while their principal use has been in connection with foreign trade, the possibility of adapting the mechanism to domestic financing requirements has been recognized for some time. Llewellyn, Some Advantages of Letters of Credit, 2 J. Bus. U. CHr. 1, 11 (1929). See Drinc-O-Matic, Inc. v. Frank, 141 F.2d 177 (2d Cir. 1944) (soda dispensing machines); Consolidated Sales Co. v. Bank of Hampton Roads, 193 Va. 307, 313-14, 68 S.E.2d 652, 656-57 (1952) (electrical appliances).

4. Today almost all commercial letters of credit are issued by banks. One of the original purposes of introducing the banks to such international sales transactions was to provide credit at banking rates rather than at the higher mercantile credit rate. WARd \& HARFIELD 7-8, 26-27; GutTeringe \& MEgRA H 4; Llewellyn, supra note 3, at 5, 14.

In banking terminology, the party who requests his bank to open a letter of credit for the benefit of another is referred to as the "customer."

5. This result has two advantages. The seller has obtained payment for the goods while they are still in transit; thus he avoids the risk of being in an unfavorable bargaining pasition should an unscrupulous buyer choose to reject otherwise satisfactory goods in the hope of being able to settle for a cheaper price. And the seller is better able to use the buyer's payment to finance his own suppliers. McGowan, Assignability of Documentary Credits, 13 Law \& Contearr. Prob. 666 (1948).

6. Maurice O'Meara Co. v. National Park Bank, 239 N.Y. 386, 146 N.E. 636 (1925); Laudisi v. American Exchange Nat'l Bank, 239 N.Y. 234, 146 N.E. 347 (1924) ; Urquhart Lindsay v. Eastern Bank, Ltd., [1922] 1 K.B. 318. See Ward \& Harfired 45; Davis 124.

7. The confirming or advising bank usually looks to the issuing bank and not to the buyer, with whom it has had no dealings. The confirming or advising bank which has become the paying bank by virtue of honoring the beneficiary's drafts may be able to collect even if the documents against which it has made payment are not conforming, so long as it offers to indemnify the issuing bank from any loss that might arise as the result of the disparity in the documents. Dixon, Irmaos \& Cia v. Chase Nat'l Bank, 144 F.2d 759 (2d Cir. 1944), ccrt. denied, 324 U.S. 850 (1945). See Backus \& Harfield, Custon and Letters of Credit: The Dixon Irmaos Case, 52 Colun. L. Rev. 589 (1952).

Whether the confirming bank would have any rights against the buyer or not would be decided by the facts of the particular case and any agreement that could be implied between them. Royal Card \& Paper Co. v. Dresdner Bank, 27 F.2d 791 (2d Cir. 1928); Kunglig Jarnvagsstyrelsen v. National City Bank, 20 F.2d 307 (2d Cir.), cert. deried, 275 U.S. 497 (1927).

The same right of reimbursement arises for an issting bank as against a correspondent 


\section{Secondary Means of Payment}

Recent banking practice has demonstrated how this simple mechanism can be employed to provide a substitute method of payment in the event the buyer does not satisfy his contractual obligation in the manner anticipated by the parties. ${ }^{9}$ In contrast to standard procedure, the letter of credit so used serves as a secondary rather than the primary means of paying a foreign supplier. ${ }^{10}$

Such a device proved ideal for an Australian importer who ordered farm machinery from an American manufacturer and planned to make payment with funds that would become available in Canada at a later date. ${ }^{11}$ The American seller, who did not insist upon immediate payment, was confident that the financing contemplated by the Australian buyer would materialize. Still, there was no reason to take unnecessary risks with a new customer. Ordinarily he would have asked the buyer for an irrevocable letter of credit naming himself as beneficiary ; this would have given him the unqualified promise of an American bank to pay against his presentation of shipping documents. In the instant case, the parties arranged for such a letter of credit, and further provided that the seller could receive payment by presenting copies of the documents to the confirming bank. Thus protected, the seller could proceed to make the shipment, forwarding the originals of the documents, and to await his money through the channel preferred by the buyer. Should the latter fail to meet his obligation through the Canadian connection, the seller could then turn to the American bank for payment.

Although such a procedure accommodates the particular needs of the parties, the establishment of alternative means of payment interjects factors not present

(usually inland) bank which has requested that the letter of credit be issued. Asbury Park \& Ocean Grove Bank v. National City Bank, 35 N.Y.S.2d 985 (Sup. Ct. 1942), aff'd mem., 268 App. Div. 984, 52 N.Y.S.2d 583 (1944), appeal denicd, 269 App. Div. 656, 53 N.Y.S.2d 458 (1st Dep't 1945) (issuing bank permitted to sell securities deposited by requesting correspondent).

8. E.g., French Am. Banking Corp. v. Isbrandtsen Co., 126 N.Y.S.2d 853, 854 (Sup. Ct.), aff'd mem., 282 App. Div. 1024, 126 N.Y.S.2d 887 (1st Dep't 1953), 307 N.Y. 616, 120 N.E.2d 826 (1954). But the beneficiary himself may have no rights against the buyer should the bank not pay against drafts which it has accepted. Vivacqua Irmaos, S.A. v. Hickerson, 193 La. 495, 190 So. 657 (1939) (bank failed).

The buyer is inclined to think in terms of the goods and not of the separate obligation to pay for the documents. Harfield, The National Bank Act and Foreign Trade Practices, 61 HARv. L. REv. 782, 784-85 (1948). But so long as the documents are satisfactory, he cannot refuse to reimburse the bank because the seller failed to satisfy the terms of the sales contract. See note 6 supra, notes 25,36 infra.

9. INTERVIEWS. The introduction of a condition to the promise of reimbursement does not render the instrument any less a letter of credit. Davis 12 .

10. The use of the word "secondary," as referring to a method of payment to which the parties will resort only in the event of the failure of a preferred method, must not be confused with the reference in suretyship law to a "secondary obligation." In these letter of credit cases the secondary means of payment is a primary obligation of the issuing bank. McCurdy, Conmercial Letters of Credit, 35 HaRv. L. Rev. 539, 715, 738 (1922). See note 40 infra.

11. INTERUIEWS. 
in the standard use of the letter of credit.12 While the seller is awaiting payment from Canada, the buyer may receive the goods and deem them nonconforming. Should he then inform the bank issuing the letter of credit, the latter might advise its correspondent to refuse payment. This development is contrary to the intent of an irrevocable letter of credit, but in practical terms the confirming bank, given such notice, will often make an effort to delay payment. ${ }^{13}$ In the meantime, the buyer could take direct action against his supplier. ${ }^{14}$ This problem seldom arises in the usual letter of credit situation, since the seller has in most instances collected from the confirming bank prior to the buyer's receipt of the goods. ${ }^{15}$ Using the letter of credit as a secondary method of payment also creates risks for the buyer, who must be careful to avoid making payment twice. An unscrupulous seller might accept funds from the Canadian source and then use copies of the documents to collect on the irrevocable letter of credit. ${ }^{10}$ To guard against this contingency, the buyer should require the seller to surrender the copies of the shipping documents as a condition of obtaining payment through the Canadian channel. ${ }^{17}$

12. It should be noted that the risk assumed by the issuing bank may be greater when the letter of credit is a secondary rather than the primary source of payment. In the standard letter of credit situation, originals of the shipping documents will be presented to the bank as a condition of the seller's obtaining payment. If the buyer who authorized the letter of credit is insolvent, the issuing bank which he is obligated to reimburse will at least enjoy a lien on the goods by virtue of possessing the shipping documents. HVIDT, BANKERS' CREDITS 79-90 (1933). Where the letter of credit serves as a secondary means of payment, the beneficiary collects against copies of the documents; possession of the copies will not suffice to give the bank a comparable lien. 2 Wirliston, Sales $\$ 441$ (rev. ed. 1948). However, the issuer will in all likelihood have demanded collateral security when the credit is opened. Comment, 65 Y ALE L.J. 807, 835 n.152 (1956).

13. Cf. note 60 infra.

14. Action directly against the seller is the buyer's only remedy. The courts frown on an attempt to enjoin payment by the bank to the seller rendering documentary performance. E.g., Williams Ice Cream Co. v. Chase Nat'1 Bank, 210 App. Div. 179, 205 N.Y. Supp. 446 (1st Dep't 1924). But see Bank of Montreal v. Recknagel, 109 N.Y. 482,17 N.E. 217 (1SSS) (discrepancy between goods and documents was evidence of fraud); note 61 infra.

15. Although the goods are normally inspected, the inspection is usually made by a party other than the buyer and the result appears as a certificate or warranty among the other documents. The seller requests a letter of credit in the first instance in order to obtain prompt payment rather than await his buyer's approval. See note 5 supra.

16. It is doubtful whether the buyer could invoke judicial aid to prevent this result. See note 14 sufra. Occasionally customers who had requested letters of credit have argued, to no avail, that courts should intervene because the beneficiary did nothing to merit payment, Nacional Financiera, S.A. v. Banco de Ponce, 275 App. Div. 827,89 N.Y.S.2d 480 (1st Dep't 1949), or because the particular goods for which the letter of credit was drawn were obtained in another manner, North Am. Manufacturers Export Associates, Inc. v. Chase Nat'l Bank, 77 F. Supp. 55 (S.D.N.Y. 1948). These cases come as close as any reported to posing the suggested problem of double payment; the answer they indicate conforms to strict commercial practice. See notes 3-8 supra and accompanying text.

17. Because of the possibility that the seller might have several copies of the shipping documents, the safest course for the buyer to take might be to require cancellation of the letter of credit as a condition of payment from the preferred source. Cf. Bank of America 
Use of a letter of credit as a supplier's secondary source of payment was developed by the Commodity Credit Corporation in its transactions with American exporters. ${ }^{18}$ The CCC is willing to provide dealers with surplus grain to be shipped abroad, but wants in exchange an equivalent value of strategic materials rather than cash. So far as the CCC is concerned, a barter transaction is contemplated. ${ }^{19}$ However, to protect itself the $\mathrm{CCC}$ requests a letter of credit which assures payment in cash should the exporter be unable to procure the stipulated materials. Immediately upon delivering the grain the CCC is eligible for payment under the letter of credit, absent a clause allowing the exporter a reasonable time to perform. But rather than collect from the bank, the $\mathrm{CCC}$ will reserve such right of payment until the exporter delivers the strategic materials and the $\mathrm{CCC}$ has had an opportunity to inspect them. If the goods are found to be satisfactory, the CCC will allow the exporter's bank to cancel the letter of credit. Should the exporter deliver the goods in installments, the CCC will advise the bank to reduce the amount of the letter of credit pro tanto until it is closed out upon the completion of the barter.

\section{Reimbursement for a Surety}

In the standard letter of credit situation, the buyer and seller anticipate that goods will be shipped and the debt which thereby arises discharged through the letter of credit. In the modifications of this pattern discussed above, the letter of credit has served as an alternative means of payment to be utilized only on the additional contingency that the preferred method fail; the parties anticipate the existence of a debt even if the letter of credit is not used to discharge it. When parties are doubtful whether or not a debt will be owed, they have sometimes employed the letter of credit to provide payment in the event that the obligation does spring into existence. Thus, in contrast to the Australian and CCC examples, the contingency determining the use of the letter of credit is not the failure of payment from a preferred source but the prospect of a debt not certain to arise. ${ }^{20}$

The contingent liability of a surety who has posted a bond is an example of an uncertain debt as the basis for a letter of credit. When the Swedish liner Stockfroldr was libeled for amounts far in excess of its value by those who had sustained losses in its collision with the ANDREA DoRIA the Swedish govern-

v. Whitney-Central Nat'l Bank, 291 Fed. 929, 935-36 (5th Cir. 1923) (other shipping documents required to verify copies).

18. INTERVIEWS.

19. The dollar volume of this bartering has been doubling each year. Since 1950 , crop exchanges have risen from less than $\$ \$, 000,000$ per year to more than $\$ 300,000,000$ in the fiscal year 1956. In the first seven months of fiscal 1957 the amount of crops released ha. already reached twice the figure for 1956; $\$ 167,000,000$ worth of lead, zinc, titanium and bauxite have been obtained as against $\$ 105,000,000$ last year. Business Week, Mar. 16, 1957 , p. 153.

20. Reference here is specifically to the underlying debt and not just to the obligation which arises upon documentary performance by the beneficiary of a documentary litter of credit. 
ment was faced with the problem of obtaining the ship's release so that it might continue operations pending settlement. The court required the Swedish government to furnish a bond for $\$ 5,000,000$, the maximum value of the STOcKHOLM and the probable limit of the owner's liability. In order to obtain such a bond, the government was obliged to have the Bank of Sweden issue, and an American bank confirm, a letter of credit naming as beneficiary the American company which was to post the bond. ${ }^{21}$ If the surety were forced to pay out under the bond, it could easily collect from the confirming bank the resulting debt owed by the Swedish government. The opening of a confirmed letter of credit was the simplest and cheapest manner of providing the bonding company with security, since the burden of depositing funds in escrow was avoided.

A situation with similar ingredients, though with overtones even further removed from the commercial arena, is the case of a bond posted in a New York court to assure compliance with a separation decree. The husband, who had obtained custody of the child, was ordered to make the child available to the wife for stipulated periods during the year. ${ }^{22}$ The requirement for posting a bond was complicated by the fact that the husband lived in Bermuda and was unable to provide security in America to the surety furnishing the bond. To obtain the bond, the husband acquired from his bank in Bermuda a letter of credit drawn in favor of the American surety company. The letter of credit was so worded that had the husband defaulted on his decree, the surety company would have been able to collect from the Bermuda bank's American correspondent the amount it was obligated to pay into court.

\section{The Letrer of Credit as Protection for a Payor}

In the preceding groups of cases, as in the traditional use of the instrument, the party authorizing the letter of credit would not be personally obligated to make payment to the beneficiary until the latter had performed a contractual obligation for his benefit. ${ }^{23}$ Thus the Australian buyer was not obligated to

21. INTERVIEWS.

22. InterviEws. Cf. Beekwilder v. Beekwilder, 29 N.J. Super. 351, 102 A.2d 642 (App. Div. 1953) (penal bond posted to assure delivery of children was forfeited to court, mother recovering damages and court retaining balance as fine); Miles v. Miles, 158 Atl. 449 (N.J. Ct. Err. \& App. 1932).

23. Of course the bank issuing the letter of credit is obligated to make payment to the beneficiary upon his documentary performance, regardless of his right to collect upon the underlying sales contract. See notes 6-8 supra, notes 25,36 infra, and accompanying text. Letters of credit have also been drawn to enable the beneficiary to obtain part payment in advance of his documentary performance. This would be the case with a letter of credit the beneficiary could pledge or assign, or the right to payment under which he would be allowed to transfer to facilitate his own financing of the transaction. McGowan, Assignability of Documentary Credits, 13 LAw \& ConteMrp. ProB. 666 (1948). This might also be said to be the case with those credits bearing a "Red Clause" which in effect gives the beneficiary even broader powers to draw drafts prior to presentation of documents. Oelbermann v. National City Bank, 79 F.2d 534 (2d Cir. 1935), modified, 298 U.S. 638 (1936). But see Grace v. Corn Exchange Bank Trust Co., 287 N.Y. 94, 38 N.E.2d 449 (1941). 
the American seller until the requested goods were received, and delivery of grain to the exporter was a condition precedent to the maturity of his indebtedness to the CCC. Similarly, the Swedish government and the Bermudian were not liable to the surety companies until the latter were required to make payment under the bonds. The letter of credit has also been employed to provide protection for a "payor" by a "performer"; that is, the party obligated by the underlying contract to tender performance establishes a letter of credit for the benefit of the party who is to pay for the performance once it has been received. As in the surety cases discussed above, the contingency determining whether the letter of credit will ever be utilized by the beneficiary is the possibility of a future debt not certain to be claimed. Whether the debt will in fact be asserted is dependent upon the beneficiary's belief as to the quality of the seller's performance.

\section{Losses in Arranging Imports}

The letter of credit opened by the performer and naming the payor as beneficiary is a protective device popular with Greek buyers who must incur comparatively large expenses in arranging an import. ${ }^{24}$ Should the American seller breach, the Greek buyer might have to forfeit sums which he has been required by his government to deposit with a bank. To cover such a loss, the buyer requires the Amferican seller to open a letter of credit for a percentage of the value of the goods ordered. The Greek buyer can then recover any expenses he must bear by collecting under the letter of credit. A certificate attesting non-performance takes the place of the documents normally presented to a confirming bank. The sole responsibility of the bank is to determine whether the presented documents conform to the requirements specified in the letter of credit. 25

24. The amount which the importer must deposit with his bank (in terms of the percentage of the value of the goods to be imported), and the sum forfeited if the import is not effected as planned, vary with the nature of the commodity. INTERNatronaL Monetary Fund, Seventh Annual Report on Exchange Restrictions 1956, at 149, 151-53.

Greece's precarious foreign exchange situation after World War II required a certificate system of allocating such foreign exchange as was available. Under such a system an importer who buys a foreign exchange certificate and then finds he has no use for it because goods are not delivered can suffer a loss. See Mikesell, Foreign Exchange IN THE POSTWAR WORID 174, 297-99 (1954). Although the foreign exchange certificate system was terminated in Greece in 1952, the letter of credit device described in the text may have been used when the system was in effect to ensure reimbursement for such a loss.

25. The bank may require strict compliance with the specifications of the letter of credit. Liberty Nat'1 Bank \& Trust Co. v. Bank of Am. Nat'1 Trust \& Sav. Ass'n, 218 F.2d 831, 840-41 (10th Cir. 1955) (draft drawn after expiration date not honored); Courteen Seed Co. v. Hong Kong and Shanghai Banking Corp., 216 App. Div. 495, 499, 215 N.X. Supp. 525, 529-30 (1st Dep't 1926), aff'd, 245 N.Y. 377, 157 N.E. 272 (1927). The bank is under no duty to look behind the documents. Maurice O'Meara Co. v. National Park: Bank, 239 N.Y. 386, 146 N.E. 636 (1925). 


\section{Faulty Performance of a Construction Contract}

Another example of a letter of credit opened by a performer for a payor was the instrument demanded by the Siamese government as a condition of awarding a contract to an American builder for the construction of a harbor. ${ }^{26}$ The government, beneficiary of the letter of credit, designated the amount of the credit; the sum was based upon the damages which might arise from unsatisfactory performance, over and above the recoupment available by not paying for such partial performance as was actually rendered. The government would have been entitled to collect under the letter of credit upon the contractor's failure to perform satisfactorily and the government's certification to the bank that a breach had occurred. The contractor who authorizes such a letter of credit is of course exposing himself to several risks. Since the bank must pay out upon the presentation by the beneficiary of a certificate alleging a breach of contract, the contractor is subjected to a unilateral determination by the beneficiary of the quality of the contractor's performance. Moreover, since performance by the beneficiary is not a condition precedent to the right of payment under the letter of credit, ${ }^{27}$ the contractor could conceivably be refused payment by the government for the harbor installation and also be forced to reimburse the bank paying under the letter of credit. This risk of double performance-once by fulfilling the contractual obligation and once by paying under the letter of credit-is not unlike the dilemma faced by the buyer in the cases where the letter of credit was utilized as a secondary means of payment. ${ }^{28}$ But while the buyer in these cases could protect himself by requiring surrender of the documents, ${ }^{20}$ analogous protection is not available to the contractor in the instant case, since payment under the letter of credit is contingent solely on the beneficiary's declaration of unsatisfactory performance.

Letters of credit designed to protect a buyer against faulty performance have also been used in connection with shipbuilding contracts. For example, a Japanese yard that is to build the ship opens a letter of credit which names as beneficiary the party ordering the ship. If the construction is not completed by the specified date, or if the builder otherwise fails to meet his contractual obligation, the letter of credit is a source of compensation for any resulting loss. ${ }^{30}$

\section{Fees}

\section{The "New" Letter of Credit and the Banks}

The recent extension in the use of letters of credit has both practical and legal implications for the banks issuing such instruments. Already they have

26. INTERVIEWS.

27. See pages $907-08$ supra.

28. See notes 9-19 supra and accompanying text.

29. See note 17 supra.

30. This credit should not be confused with the one running to the shipbuilder. The letter of credit mechanism has also been made available to assure the shipbuilder of financing as he completes construction. INTERVIEWS. 
made appropriate mechanical adjustments. A common practice has been for the bank to charge the customer requesting issuance of a credit on two separate occasions: when the instrument is issued and when payment is made under it. ${ }^{31}$ But if the letter of credit is a secondary means of payment, or is to be utilized only upon the happening of a contingency the occurence of which is doubtful, experience has shown that the beneficiary rarely demands payment and the letter of credit is simply permitted to lapse. ${ }^{32}$ Because banks believed they were not adequately compensated for the risk assumed when the customer made only one payment under the traditional schedule of charges, they were led to revise their practice as to those instruments under which future payment is unlikely. They now charge a flat fee on the opening of such a letter of credit, a sum geared both to the amount of the credit and to the length of time it is to remain valid. ${ }^{33}$

\section{Documents}

Banks have also realized that modern developments in the use of letters of credit have radically changed the nature of the documents which the beneficiary must present to them to obtain payment. ${ }^{34}$ Admittedly in the Australian

31. Actually there is no uniform method of payment, let alone a standard charge, for letters of credit. But because there are costs which arise in connection with having the letter of credit confirmed, advised and paid, splitting the charge in this manner has been practiced by several banks. INTERviEws.

The nature of the security which the bank often requires the customer to deposit before it will extend credit is influential in determining the charge that will be levied. Ibid. See Asbury Park \& Ocean Grove Bank v. National City Bank, 35 N.Y.S.2d 985 (Sup. Ct. 1942), aff'd mem., 268 App. Div. 984, 52 N.Y.S.2d 583, appeal denied, 269 App. Div. 656, 53 N.Y.S.2d 458 (1st Dep't 1944).

32. For example, bankers interviewed know of no instance in which the CCC has resorted to a letter of credit for payment because of the failure of a grain exporter to deliver strategic materials.

33. The new kind of letter of credit described in text is opened for a given period of time, usually no longer than one year. The flat fee which will be charged for the credit may be made payable quarterly. In the event the credit is terminated prior to its expiration date, the bank, at its discretion, may not require payment for subsequent quarters. INIERvIEws.

34. Of the several variations in form of the letter of credit, see note 2 sulpra, the distinction between a clean and a documentary credit is of most significance in the present context. The bank issuing a clean letter of credit undertakes to pay drafts drawn upon it without any documents attached. Bills drawn under a documentary letter of credit will be honored only if they have attached to them specified documents, e.g., seller's invoice, bill of lading, insurance policy, consular invoice, certificate of weight or quality, export license. Compare "Clean Letter of Credit," Finkelstern 297, with "Irrevocable Straight Letter of Credit," id. at 300. See American Nat'l Bank \& Trust Co. v. Banco Nacional de Nicaragua, 231 Ala. 614,166 So. 8 (1936), judgment aff'd on new opinion, 238 Ala. 128, 189 So. 191 (1939).

In addition to documents, there are other conditions which can be written into a letter of credit. Commercial Union of America v. Anglo-South American Bank, Ltd., 16 F.2d 979 (2d Cir. 1927) (credit required specific sailing time); United States Steel Products Co. v. Irving Bank-Columbia Trust Co., 9 F.2d 230 (2d Cir. 1925) (credit required goods not 
and CCC cases the documents specified in the letters of credit were substantially the same as would be required in the standard use of the instrument. But a written notice of payment under a surety bond, or a certficate attesting unsatisfactory performance of a contract, is hardly characteristic of the kind of document which banks have traditionally inspected for conformity. The extreme case in this respect was that of the attorney who required his client to open a letter of credit to assure him payment for securing a divorce. ${ }^{35}$ The parties agreed that the divorce papers would constitute the documents which would be presented to the bank by the attorney-beneficiary. A bank is entitled to reimbursement as long as the documents against which it makes payment accord with the requirements set out in the letter of credit. ${ }^{36}$ Accordingly, the wide variety of unique documents which may be presented offer an increased risk that the bank will be charged with improper payment. ${ }^{37}$

\section{Problems of Ultra Vires}

National and state banks generally lack the statutory power to guarantee the indebtedness of other parties. ${ }^{38}$ The commercial letter of credit, as traditionally

be shipped before June) ; Banco Nacional de Credito v. Bank of America, 118 F. Supp. $30 S$ (N.D. Cal. 1954) (reinstatement of credit required advice that documents had been forwarded). Whether a bank is under any greater duty to investigate the representation of the fulfillment of such conditions than it is to ascertain the facts behind shipping documents is basic to the present discussion. For the sake of conformity and commercial expediency there should be no greater burden on the banks. But notice to the bank of nonoccurrence of such a condition may defeat the beneficiary's right to payment while notice of non-conforming goods behind conforming documents would have no such effect. Compare Commercial Union of America v. Anglo-South American Bank, supra, with Continental Nat'1 Bank v. National City Bank, 69 F.2d 312 (9th Cir.), cert. denied, 293 U.S. 557 (1934).

35. INTERVIEWS.

36. E.g., C. Lievense, Ltd., v. Credit Suisse, 285 App. Div. 1046, 140 N.Y.S.2d 3 (1st Dep't 1955) (letter from bank holding warehouse receipts satisfied requirement). See notes 25,34 supra and accompanying text.

37. As a general rule, the bank must pay only if the documents are in "strict" compliance with the terms of the credit. E.g., Crocker First Nat'1 Bank v. De Sousa, 27 F.2d 462 (9th Cir.), cert. denicd, 278 U.S. 650 (1928); Lamborn v. Lake Shore Banking \& Trust Co., 196 App. Div. 504, 188 N.Y. Supp. 162 (1st Dep't), aff'd, 231 N.Y. 616, 132 N.E. 911 (1921). However, when the bank seeks reimbursement from its customer, compliance requirements are usually more relaxed. See authorities cited Comment, $62 Y_{\text {ALE }}$ L.J. 227, $248 \mathrm{n} .107$ (1953).

38. 1 Morse, Banks and Banking $\S 65$, n.1 (6th ed. 1928); 6 Fietcher, Cyclopedia of Corporations $\$ 2592$ (1950). The prohibition is actually based on a negative inference from statutes and bank charters. National banks, for example, have only such powers as they are expressly given. Colorado Nat'l Bank v. Bedford, 310 U.S. 41, 48-50 (1940); Texas \& Pac. Ry. v. Pottorff, 291 U.S. 245, 253 (1934) (national banks not allowed to pledge assets to secure deposits). The same is true with respect to state banks. Smyth v. Kaspar Am. State Bank, 9 Ill. 2d 27, 136 N.E.2d 796 (1956). Although national banks are empowered to conduct transactions "necessary to carry on the business of banking," Kiev. STAT. 5136 (1875), as amended, 12 U.S.C.A. $\$ 24$ (Supp. 1956), the issuance of guaranties is not generally considered integral to banking practice. See authorities cited in Harfield, The National Bank Act and Foreign Trade Practices, 61 HArv. L. Rev. $782,788 \mathrm{n} .12$ (1948). Thus, in the absence of an express grant, bank guaranties are ultra 
used, has been held not to constitute a guaranty. ${ }^{39}$ Courts have reasoned that the issuing bank is not responsible for the debt of another; rather, it incurs a distinct, independent obligation to pay the beneficiary upon presentation of conforming documents, regardless of the liability of the buyer on the underlying sales contract. ${ }^{40}$ If this reasoning is not equally applicable to the recent uses

vires acts. Merchants' Nat'1 Bank v. Baird, 160 Fed. 642, 645 (Sth Cir. 1908); Harfield, supra at 795.

There are some state banks to which the power to issue guaranties has been expressly granted. INTERviEws.

39. "[The letter of credit] is not analogous to the situation which prevails in suretyship; the [buyer] could assert or fail to assert its rights against the seller under the sales contract, and its action in that regard has no bearing upon its rights under the independent letter of credit contract with these [banks]." Overseas Trading Corp. v. Irving Trust Co., 82 N.Y.S.2d 72, 76 (Sup. Ct. 1948).

See Campbell, Guaranties and the Suretyship Phases of Letters of Credit, $85 \mathrm{U}$. PA. L. Rev. 175, 261 (1936) ; Trimble, The Implied Power of National Banks to Isste Lettcrs of Credit and Accept Bills, 58 Y YLE L.J. 713 (1949). See also Consolidated Sales Co. v. Bank of Hampton Roads, 193 Va. 307, 68 S.E.2d 652 (1952) ; Davis 59-60; FINIKELSTEIN 32-42; GUTTERIDGE \& MEgRAH 17.

The power to issue letters of credit is often granted by statute. See 41 Stat. 378 (1919), as amended, 12 U.S.C.A. $\$ 615$ (Supp. 1956) (national banks engaged in foreign transactions); CAL. FIN. Code ANN. \$ 1224 (Deering Supp. 1955) (documentary credits may be issued in specified transactions involving the sale of goods); N.Y. BANKING LAW $\$$ 96(2). Since letters of credit are in every-day commercial usage, the power to issue them may also be implied from statutory grants to engage in activities "necessary to carry on the business of banking." See note 38 supra; Llewellyn, quoted in WARD \& HARFIELD 68-72; Comment, 62 Y ALE L.J. 227, 231 n.24 (1953).

40. "Unless express conditions are contained in the letter of credit, the performance of the sales contract between the buyer and seller is not a condition precedent of the credit or of the buyer's agreement to reimburse. The letter of credit is a wholly independent contract ...." Kingdom of Sweden v. New York Trust Co., 197 Misc. 431, 441, 96 N.Y.S.2d 779, 787 (Sup. Ct. 1949). See American Steel Co. v. Irving Nat'1 Bank, 266 Fed. 41, 44 (2d Cir. 1920) (letter of credit held to be contract between plaintiffbeneficiary and defendant-issuing bank; bank required to pay) ; Lamborn v. Lake Shore Banking and Trust Co., 196 App. Div. 504, 188 N.Y. Supp. 162 (1st Dep't), aff'd per curian, 231 N.Y. 616, 132 N.E. 911 (1921) (bank not required to pay on its contract with beneficiary although goods satisfied sales contract).

The independence of the bank's undertaking is reflected in several ways. Payment by the bank not in accordance with the terms of the credit gives the bank no right of reimbursement; furthermore, any deposit which the customer may make with the bank to secure the letter of credit is not to be considered as payment to the seller by the buyer. Caloric Stove Corp. v. Chemical Bank \& Trust Co., 205 F.2d 492 (2d Cir. 1953) ; Citizens Nat'l Trust \& Sav. Bank v. Londono, 204 F.2d 377, 379 (9th Cir. 1953) (concurring opinion) (same).

Other arguments have been made to refute the contention that the bank's undertaking on a credit constitutes a guaranty. The buyer and seller are able to amend the underlying sales contract in a manner that would vitiate any guaranty by a third party, and there is no requirement of the bank's having knowledge of seller's acceptance of the "guaranty" as a condition of being bound. Lamborn v. National Park Bank, 212 App. Div. 25, 208 N.Y. Supp. 428 (1st Dep't), aff'd, 240 N.Y. 520, 148 N.E. 664 (1925). See Lane Bros. Co. v. Sheinwald, 275 Mass. 96, 175 N.E. 148 (1931) ; Hershey, Letters of Credit, 32 HARv. L. Rev. 1, 14 (1918). 
of the letter of credit, then these transactions may conceivably be branded ultra vires. ${ }^{41}$

Where the letter of credit is a secondary means of payment, the bank is in reality guaranteeing payment to the seller in the event that the buyer does not make payment from a preferred source. However, the seller does have a right to collect under the letter of credit as soon as the goods are shipped; the bank must pay even though the beneficiary has made no attempt to obtain payment in the manner anticipated by the parties. In this respect the letter of credit still constitutes an independent obligation of the bank to the beneficiary, rather than a promise to pay in case the buyer does not. Had the parties provided that the beneficiary could not collect on the letter of credit until he certified he could not obtain payment from the preferred source, the transaction might well have been deemed a guaranty, and subject to attack as ultra vires.

When a surety company has been named beneficiary of a letter of credit and is thereby enabled to recoup the sums paid out under a bond, the effect of the arrangement for the surety company is one of indemnity. Likewise, the customer who has provided the surety company with the letter of credit has done so with the express purpose of facilitating reimbursement. If the bank is itself deemed to have issued an indemnity, it will probably have acted ultra vires, since an agreement to indemnify is subject to the same proscription as a contract of guaranty. 42

An "ultra vires" assertion could be supported by the seeming absence in these cases of independent liabilities. In the standard letter of credit situation, the performance which obligates the bank to pay the beneficiary is not the same as the performance which gives the seller rights against the buyer. The bank must pay upon presentation of conforming documents; the buyer must pay upon delivery of conforming goods. ${ }^{43}$ The fact that the bank may be liable though the buyer is not personally indebted is the reason why the letter of credit has been considered an independent obligation and not a promise to answer for the debt of another. When a letter of credit is a device to reimburse a surety, it may be contended that the foregoing analysis is inapplicable on the following grounds: the duty of the bank to pay the surety arises when the latter pays money to discharge an obligation of the party authorizing the letter of credit. Such payment under the bond simultaneously creates for the surety rights of reimbursement against the party for whose benefit the bond had been posted. Accordingly, any claim that the bank is not responding for another's debt is erroneous, since the party authorizing the letter of credit

41. Since the prohibition against guaranties is based solely on a negative inference, see note 38 supra, it may be argued that where a bank is expressly empowered to issue a litter of credit, see note 39 supra, a credit which is considered a guaranty is nonetheless valid. However, because of the settled rule against guaranties, a court might still be unwilling to estend the letter of credit mechanism beyond its traditional non-guaranty use.

42. 7 Michie, Banks and Banking \$ 163 (perm. ed. 1944); Ward \& Harfield 60.

43. See notes 3-8 supra and accompanying text. 
becomes personally indebted by the same performance as gives rise to rights against the bank.

This argument could be countered by the contention that the obligation of the bank to the beneficiary technically arises not when the surety has in fact paid out under the bond, but when the surety certifies to the bank that it has made such a payment. Thus, if a surety falsely certified that money has been expended, the bank would be obligated to pay against the presentation of conforming documents; unlike the party for whom the bond had been posted, the bank could not defend on the ground that no payment had actually been made.44 Although it is highly unlikely that the surety would falsely certify payment, the very fact that the bank would have to pay if it did is an indication that the bank has issued a letter of credit and not an indemnity contract or guaranty. Moreover, the surety might pay out under the bond in the mistaken belief that the party for whom the bond was posted was liable to the party paid.45 Under these circumstances, the surety would be entitled to collect from the bank, but such payment could not be deemed in discharge of the debt of another, since the surety would have no right to collect directly from the party it had bonded. ${ }^{46}$

When a letter of credit is used as source of compensation for unsatisfactory performance by a seller, ${ }^{47}$ the nature of the bank's undertaking raises the same

44. Non-payment behind an otherwise regular certificate would constitute no greater defense than non-delivery behind conforming documents. See Maurice O'Meara Co. v. National Park Bank, 239 N.Y. 386, 146 N.E. 636 (1925); note 34 supra.

False documents present a difficult problem. The risk of forged instruments is on the buyer; paying or negotiating banks do not warrant that the documents are genuine. See Davis 155-66; Finkelstein 246-48; GutTermae \& Megrat 101-04; Wand \& Harfield 54-55.

45. Payment by the surety under a mistake of fact would give it no right of reimbursement against the principal debtor unless that mistake of fact were occasioned by a misrepresentation or act, such as release of security, on the part of the principal. ArAwt, SURETYSHIP AND GUARANTY $\$ \S 62,73$ (1931).

46. Some of the cases which have considered whether a letter of credit is a guaranty contain language which might be the basis of an additional contention that the letter of credit extended to the surety is not ultra vires. These cases imply that the bank is not a guarantor because it is obligated to pay the beneficiary, even though the latter has made no effort to collect the price of the goods from the buyer who is liable on the underlying sales contract. In terms of the common law of guaranty, such an observation would seem to indicate only that the bank is a guarantor of payment and not of collection. See Sturges, CREDit Transactions 2, 46-50 (4th ed. 1955). However, some courts have apparently felt that, since the bank must pay prior to any demand upon the buyer, the bank incurs a "primary obligation" which should not be deemed an ultra vires guaranty. See, e.g., Kingdom of Sweden v. New York Trust Co., 197 Misc. 431, 441, 96 N.Y.S.2d 779, 787 (Sup. Ct. 1949) ; Overseas Trading Corp. v. Irving Trust Co., 82 N.Y.S.2d 72 (Sup. Ct. 1948). If a court accepts this theory, the letter of credit for the surety will not be held ultra vires, since demand upon the bonded party for reimbursement is not a condition precedent to the bank's duty to pay. A similar argument against ultra vires could be made as to every letter of credit which does not require the beneficiary to look initially to the resources of the party authorizing the instrument.

47. See text at notes 23-30 supra. 
question of an ultra vires guaranty. In reality, the bank which pays the beneficiary of such a letter of credit may be said to answer for the unliquidated debt of the performer arising from his breach. Yet, the bank must make payment upon the beneficiary's allegation that a breach has occurred; the seller who has authorized the letter of credit would be personally indebted to the buyer only if a breach had in fact occurred, as evidenced by a judgment awarding damages. Thus the letter of credit may again be deemed an "independent obligation" of the bank rather than a guaranty, since the bank might be indebted to the beneficiary while the seller was not.

Even assuming that a letter of credit could be proven ultra vires, a customer who had requested that the letter of credit be opened would probably be estopped from refusing the bank's demand for reimbursement on that ground. ${ }^{48}$ However, a bank, either on its own motion ${ }^{49}$ or on behalf of the customer, may be able to assert ultra vires as a reason for refusing payment to a beneficiary who had complied with the terms of an irrevocable letter of credit. ${ }^{50}$ The

48. Ultra vires is not favored by the courts as a defense. 7 Fletcher, Cyclopedia of CoRporations $\$ 3407$ (1931). A party dealing with a corporation is estopped if the corporation has acted in reliance on the contract sought to be invalidated. Id. $\$ 3409$. Such reliance would clearly seem to have occurred if the bank has paid the beneficiary under the credit.

Knowledge on the customer's part that the bank's guaranty would be outside its powers is grounds for estoppel against the customer. Bowen v. Needles Nat'l Bank, 87 Fed. 430, 443 (C.C.S.D. Cal. 1898) ; Kaplan v. Topinka, 291 Ill. App. 222, 9 N.E.2d 470 (1937). Persons dealing with a national bank are chargeable with knowledge of the limitations imposed upon it. California Bank v. Kennedy, 167 U.S. 362 (1897); McCormick v. Market Bank, 165 U.S. 538, 549-50 (1897). The same is true with respect to state banks. Smyth v. Kaspar Am. State Bank, 9 Ill. 2d 27, 136 N.E.2d 796 (1956). But "the mere giving of a guaranty or of an undertaking is not in and of itself a wrong, illegal, or beyond the corporate powers of a bank." American Surety Co. v. Philippine Nat'1 Bank, 245 N.Y. 116, 130-32, 156 N.E. 634, 639-40, cert. denied, 275 U.S. 549 (1927) (Philippine bank whose charter not entered into evidence held liable on guaranty). "The contract with the plaintiff on its face was not necessarily beyond the scope of the power of the bank."

It has been said that only the state, and not a private party, can object to a bank's undertaking as ultra vires. Kerfoot v. Farmers' \& Merchants' Bank, 218 U.S. 281 (1910); Jackman v. Continental Nat'l Bank, 16 F.2d 728, 733 (8th Cir. 1926). But see 7 FLETCHER, Cyclopedia of Corporations $\$ 3444$ (1931).

49. The bank would be likely to act on its own motion if it would be unable to obtain reimbursement for any sums paid the beneficiary because of the customer's present insolvency. In addition, the bank would lack a security interest in goods which it enjoys under the standard letter of credit. See note 12 supra.

50. So long as an ultra vires contract is still wholly executory, an action cannot be maintained against the corporation on the contract in most jurisdictions. 7 FLETCHER, CyClopedia of CoRPoRAtions $\$ 3460$ (1931). However, if the beneficiary has acted in reliance upon the irrevocable letter of credit which the bank has been paid to open, the contract could not be considered executory. Despite such reliance on the part of the beneficiary, under the so-called federal rule the bank could still urge ultra vires as a valid defense to payment: the ultra vires contract would be void and unenforceable. Awotin v. Atlas Exchange Nat'l Bank, 295 U.S. 209 (1935); California Bank v. Kennedy, 167 U.S. 362 (1897). The bank would not be estopped to deny its validity. Cassatt v. First Nat'l Bank, 9 N.J. Misc. 848, 156 At1. 278 (Sup. Ct. 1931), aff'd, 111 N.J.L. 536, 168 Atl. 585 (Ct. Err. \& App. 1933) ; Century Federal Sav. 
ultra vires question might also be raised by shareholders, ${ }^{51}$ by depositors. ${ }^{62}$ or by bank regulatory authorities anxious to terminate the issuance of this particular kind of letter of credit.53

\section{The Letter of Credit as an Unenforceable Penalty}

In addition to the ultra vires question, the recent uses of the letter of credit raise issues of penalties and liquidated damages. The instruments which were

\& Loan Ass'n v. Sullivan, 116 N.Y.S.2d 323 (Sup. Ct. 1952), modified, 281 App. Div. 830, 118 N.Y.S.2d 479 (2d Dep't 1953). See Texas \& Pac. Ry. v. Pottorff, 291 U.S. 245, amended on other grounds, 291 U.S. 649 (1934) (rule of no estoppel declared for corporations in general). And the beneficiary would be charged with knowledge of the ultra vires nature of the contract. State Bank v. Benzing, 383 Ill. 40, 48 N.E.2d 333 (1943); Knass v. Madison \& Kedzie State Bank, 354 Ill. 554, 188 N.E. \$36, appeal dismissed, 292 U.S. 599 (1934).

Some states deny a corporation the defense of ultra vires where the contract was entered into in good faith and the corporation has received benefit therefrom. City of Yonkers v. Downey, 309 U.S. 590 (1940) (New York rule); Wagner v. Somerset County Memorial Park, Inc., 372 Pa. 338, 93 A.2d 440 (1953) ; McLean Co. v. Sidebottom, 277 Miass. 158,178 N.E. 284 (1931). It has been held that such a doctrine, though applicable to corporations generally, should not be applied to banks. Missouri State Life Ins. Co. v. Lakeland Star-Telegram Co., 111 Fla. 416, 149 So. 597 (1933). But cf. California Funding Corp. v. Long Beach Nat'1 Bank, 134 Cal. App. 2d 343, 285 P.2d 721 (1955) (act of bank not necessarily void though ultra vires according to banking laws). Mforeovrr, it could be contended that the benefit which accrues to the bank from the ultra vires guaranty (i.e., payment by the customer, or the customer's promise to pay if the fee was not collected by the time the beneficiary demanded payment from the bank) is not substantial enough to preclude establishing the ultra vires nature of the contract as a defense. Sec Hamburg Bank v. Ouachita Nat'l Bank, 78 F.2d 100, 105 (8th Cir. 1935); In re Steele Furniture, 18 F.2d 490 (3d Cir.), cert. denied, 274 U.S. 758 (1927) ; cf. Evans v. Johnson, 149 Fed. 978 (9th Cir. 1896) (no estoppel because third party, and not corporation, held to have received benefit from ultra vires guaranty).

If reimbursement could not be obtained from the customer, it is highly doubtful whether a bank could utilize an ultra vires contention to recover such payments as it may have already made to the beneficiary. Quintal v. Fidelity \& Deposit Co. of Maryland, I42 N.Y. Misc. 657, 663, 255 N.Y. Supp. 259, 263 (Sup. Ct. 1932), aff'd mem. 238 App. Div. \$20, 262 N.Y. Supp. 924 (1st Dep't 1933). But cf. Baltimore \& O.R.R. v. Smith, 56 F.2d 799, $\$ 03$ (3d Cir. 1932) (deposit of securities with national bank voided).

51. Dissenting shareholders sometimes may sue to enjoin the execution or performance of an ultra vires contract where neither party to the contract could set up the claim. 7 Fletcher, Cyclopedia of Corporations $\$ \$ 3443,3453$ (1931).

On the other hand, if the corporation is estopped from bringing an action, the shareholders of the corporation may also be barred. French v. Long, 42 F.2d 45, 47 (4th Cir. 1930).

52. Fort Worth v. McCamey, 93 F.2d 964, 967 (5th Cir.), cert. denied, 304 U.S. 571 (1938) (depositors can bring action to void ultra vires pledge despite comptroller's ruling and receiver's inaction).

53. The stability of banks is a matter of public concern; banking authorities are expected to investigate the activities of banks in order to discover invalid acts. Continental Bank \& Trust Co. v. Woodall, 239 F.2d 707, 710 (10th Cir. 1957) (continuing duty of Federal Reserve Board); State Bank of Commerce v. Stone, 261 N.Y. 175, 188, 184 N.E. 750,754 (1933). 
authorized by "performers" for the benefit of "payors" resemble a form of penal hond. In its modern garb, such a bond would create a duty of payment by the obligor in the event that the party bound by a contractual obligation does not render the promised performance within the specified time. ${ }^{54}$ In order to collect from the obligor, the promisee must prove both the execution of the bond and a failure of performance. ${ }^{55}$ Moreover, since the law limits the freedom of contracting parties by refusing to enforce an agreement which imposes a penalty for a breach of contract, the general rule is that the promisee may enforce the undertaking of the obligor only to the extent of the damage proved to have been incurred by reason of the promisor's breach. ${ }^{56}$ However, the promisee may be able to collect the full amount of the bond as liquidated damages for the breach if the designated sum is found to be a reasonable prediction of the injury which would be caused by a failure of performance, ${ }^{57}$ and if, at the time of contracting, it had appeared that the actual damage flowing from a breach would be difficult to ascertain. ${ }^{58}$

Like the penal bond, the letter of credit designed to compensate a beneficiary for a contractual breach imposes a duty upon a third party to pay a fixed sum to a promisee in the event of a failure of performance. Yet, the beneficiary of such a letter of credit enjoys an important advantage over the obligee of a penal bond: the obligee to collect must sustain the burden of proving at trial a breach of contract and the resulting injury, while the beneficiary may obtain any amount up to the designated sum merely by alleging to the bank a failure of performance and the extent of his damage.59 Thus, the judicial scrutiny which accompanies the modern penal bond is not found in the letter of credit mechanism. But a court might be asked to intervene if a bank, acting in its own interest or at the request of the customer, refused payment to the beneficiary on the ground that the letter of credit awarded a promisee an unen-

54. 5 Corbin, Contracts $\$ 1056$ (1951).

55. Ibid.

56. National Cooperative Refinery Ass'n v. Northern Ordnance, 238 F.2d 803,807 (10th Cir. 1956) ; Lunt, Surety Bonds 196-197 (1922). Similarly, if funds are deposited in escrow to assure performance of a contract, the party injured may collect only the actual amount of his damage, see Restatenrent, Contracts $\$ 340$ (1932) ; 5 Corbin, Contracts $\$ 1074$ (1951); 3 WILLISTON, Contracts $\$ 790$ (rev. ed. 1936), unless the sum constitutes a valid provision for liquidated damages, see notes 57,58 infra and accompanying text.

57. Restatement, Contracts $\S 339$ (1) (a) (1932); 3 Williston, Contracts $\$ 783$ (rev. ed. 1936).

58. Ely v. Wickham, 158 F.2d 233, 234 (10th Cir. 1946) ; Restatenent, Contracts $\$ 339$ (1) (b) (1932); 3 Williston, Contracts $\$ 783$ (rev. ed. 1936). The obligor may not be held liable for a greater sum than the amount of the bond plus interest. Bill Curphy Co. v. Elliott, 207 F.2d 103 (5th Cir. 1953) ; see Restatearent, Contracts $\$ 339$ (2) (1932); 5 CORBIN, Contracts $\$ 1056$ (1951).

59. Thus, while the contention that the letter of credit is not ultra vires as a guaranty may be sustained by emphasizing the independent and automatic obligation of the bank to pay, see note 40 supra, this same feature of the letter of credit may lead to its invalidation as a penalty. 
forceable penalty for a breach of contract. ${ }^{60}$ The question of a penalty might also be raised if the customer sought to enjoin payment by the bank. ${ }^{01}$ Moreover, the customer might sue the beneficiary to recover sums which the bank had paid, alleging that no breach had occurred or, if there were a breach, that the amount collected from the bank far exceeded actual damage.

The traditional judicial hostility to penalties in the law of contract would seem to constitute a potential infringement upon the protection enjoyed by a beneficiary, when a letter of credit is established as a source of compensation for unsatisfactory performance. If a bank refused to pay the beneficiary, asserting that the instrument authorized a penalty, a court would undoubtedly be indifferent to the fact that the promisor had voluntarily provided the irrevocable letter of credit as security for his own performance. ${ }^{62}$ The proscription against penalties has long been recognized as a deviation from the principle of freedom of contract, founded upon overriding considerations of public policy. ${ }^{63}$

60. Although, in this context, the letter of credit resembles a penal bond, its validity is less likely to be tested. Eager to retain its credit standing, a bank might be unwilling to raise the penalty issue as a basis for refusing payment after conforming documents have been tendered. However, if the bank were more concerned with the good will of its customer or elected to avoid a loss that would result were the customer unable to reimburse, see note 49 supra, the penalty question might be raised to block payment. See Comment, 65 Y ALE L.J. 807, 836 (1956). And while such a blocking of payment is contrary to the entire letter of credit concept, a court might well allow it as a defense because of the strong public policy against penalties and devices contrived to provide for them. See note 63 infra and accompanying text. To buttress its contentions, the bank could point to cases holding the prohibition against penalties applicable to funds deposited with an escrow agent, see note 56 supra. Cf. Bogert, Trusts and Escrozes in Credit Convcyancing, 21 ILL. L. REv. 655, 672-75 (1927).

61. In the traditional buyer-seller context, such requests for injunctive relief have by and large been unsuccessful. See note 16 supra. There is case law, however, to the effect that evidence of fraud will sustain an injunction against the issuing bank even though the documents tendered conform to the terms of the credit. See Bank of Montreal v. Recknagel, 109 N.Y. 482, 17 N.E. 217 (1888) ; Sztejn v. J. Henry Schroder Banking Corp., 177 Misc. 719, 31 N.Y.S.2d 631 (Sup. Ct. 1941) ; Grob v. Manufacturers Trust Co., 177 Misc. 45, 29 N.Y.S.2d 916 (Sup. Ct. 1941) (dictum). Compare American Steel Co. v. Irving Nat'1 Bank, 266 Fed. 41 (2d Cir. 1920), cert. denied, 258 U.S. 617 (1922) (issuing bank must honor drafts although performance of sales contract might be illegal), with Nadler * v. Mei Loong Corp. of China, Ltd., 177 Misc. 263, 30 N.Y.S.2d 323 (Sup. Ct. 1941) (showing of hardship warrants injunction against payment). Arguing that commercial policy requires the prevention of burdensome penalties as well as the policing of fraud, a customer could conceivably obtain an injunction to litigate the penalty issue.

62. Almost any anticipatory provision for a penalty is regarded with disfavor. Cf. 66 HARV. L. REV. 525 (1953).

In any event, the terminology employed by the parties-"liquidated damages" or "penalty" - will be of little significance to the court. United States v. Bethlehem Steel Co., 205 U.S. 105 (1907) ; Nacional Financiera, S.A. v. Banco de Ponce, 275 App. Div. 827, 89 N.Y.S.2d 480 (1st Dep't 1949). But see Bauer v. Sawyer, 8 I11. 2d 351, 134 N.E.2d 329 (1956) (use of word "forfeit" persuasive).

63. 5 CoRbrn, Contracts $\S 1057$ (1951).

On the other hand, courts will recognize as valid a provision in a contract limiting the liability of the parties in the event of default. Restatexent, Contracts $\$ 3339$, 
Moreover, the penalty aspect of the letter of credit mechanism is magnified by the fact that the promisee is relieved of proving not only the extent of his damage but also that the contract was actually breached. ${ }^{64}$

Assuming that this unilateral determination of breach would not make the instrument fatally defective as a penalty, the beneficiary who is refused payment might be able to convince the court that the amount specified in the letter of credit represents a valid provision for liquidated damages. ${ }^{65}$ However, in the case of the letter of credit opened for the Greek buyer, ${ }^{66}$ the loss which would be caused by the seller's breach would appear to be easy to calculate; hence one of the prerequisites for enforcing a provision fixing damages in advance would be absent. In the case of the letters of credit authorized by the American harbor builder ${ }^{67}$ and the Japanese shipyard, ${ }^{68}$ one kind of breach which the parties contemplate is the possibility that performance will not be completed by the specified date. Courts have upheld, as a valid provision for liquidated damages, an agreement binding a contractor to pay a fixed sum for each day's tardiness in concluding performance. ${ }^{69}$ In contrast to such an arrangement, the letter of credit mechanism permits the beneficiary to collect the full amount of the instrument, regardless of the extent to which performance is in fact delayed. ${ }^{70}$ Thus a court may find a penalty element present, since the promisee is enabled to obtain a sum grossly disproportionate to the actual harm which a limited delay in performance may be expected to cause. ${ }^{71}$ In addition to tardiness, the letter of credit secures the beneficiary against

574-75 (1932); 5 Corbin, Contracts $\S 1068$ (1951); 3 Wiliston, Contracts $\S 781 \mathrm{~A}$ (rev. ed. 1936); Brightman, Liquidated Damages, 25 Colum. L. Rev. 277 (1925).

64. The party who would collect under a standard liquidated damage clause is obliged to prove breach but not the extent of the injury. 5 Corbrn, Contracts $\S 1062$ (1951). See Union Paving Co. v. United States, 115 F. Supp. 179 (Ct. Cl. 1953).

65. See 5 Corbin, Contracts $\$ 1061$ (1951); 3 Williston, Contracts $\$ 783$ (rev. ed. 1936) ; Kothe v. R. C. Taylor Trust, 280 U.S. 224, 226 (1930); Steffen v. United States, 213 F.2d 266, 270 (6th Cir. 1954).

66. See notes 24-25 supra and accompanying text.

67. See notes 26-29 supra and accompanying text. Because the beneficiary in this case would be a sovereign power it is possible that the letter of credit would be accorded the more protected status afforded penal bonds posted to secure public construction. Steffen v. United States, 213 F.2d 266 (6th Cir. 1954); 5 Corbin, Contracts $\S 1055$ (1951) ; cf. Rex Trailer Co. v. United States, 350 U.S. 148, 153 (1956). But cf. Priebe \& Sons, Inc. v. United States, 332 U.S. 407 (1947) (sovereign has no implied authority to impose penalty).

68. See note 30 supra and accompanying text.

69. Broderick Wood Products Co. v. United States, 195 F.2d 433, 438 (10th Cir. 1952); United States v. American Employers Ins. Co., 141 F. Supp. 281, 291 (E.D. Pa. 1956); 5 CoRdin, Contracts $\$ 1072$ (1951); 3 Williston, Contracts $\$ 785$ (rev. ed. 1936).

70. INTERVIEWs. In practice, however, beneficiaries of this kind of letter of credit have, in the event of a breach, collected only that amount which they believe to be a fair estimate of the actual damage suffered. Ibid. This result is of course not inherent in the terms of the letter of credit, but is attributable solely to the good faith of the beneficiary.

71. Marshall v. Patzman, 306 P.2d 287 (Ariz. 1957); 5 CoRBIn, Contracts $\$ 1063$ (1951); 3 Williston, Contracts $\$ 779$ (rev. ed. 1936). 
a breach of warranty arising from a defective job of construction, and against the failure of the contractor to make any performance at all. An agreement fixing liquidated damages for either of these breaches might be invalidated on the ground that the actual injury which would be incurred by the promisee is readily susceptible of determination. ${ }^{72}$ Moreover, the whole letter of credit mechanism could be attacked as a penalty for the reason that it permits an identical amount to be made payable, irrespective of the nature of the breacl or the actual extent of the injury. ${ }^{73}$

Thus, when a contracting party authorizes a letter of credit as protection against faulty performance, the beneficiary is subject to the risk that, despite the express terms of the instrument, payment cannot be enforced against the bank upon a mere allegation of breach and the amount of damage. While the beneficiary would still enjoy the security of the bank's credit, he would lase the advantage of escaping burdens of proof and, like any other promisee, would have to establish at trial that he was entitled to a specific amount from the bank as compensation for a contractual breach.

When the letter of credit serves as an alternative means of payment, the penalty and liquidated damage questions are not as relevant. Payment under the letter of credit would seem to constitute a performance discharging the buyer's contractual obligation rather than the collection of damages for unsatisfactory performance. ${ }^{74}$ Such an arrangement is no more of a penalty than if a buyer deposited in escrow the purchase price of goods, to be collected upon the seller's delivery of the merchandise. However, a claim of penalty might be raised if the amount which the seller was entitled to collect under the letter of credit exceeded the sum owed if payment were made by the primary means. ${ }^{75}$

72. Hugo V. Loewi, Inc. v. Geschwill, 186 F.2d \$49, 857-58 (9th Cir. 1951) ; A-Z Servicenter, Inc. v. Segall, 138 N.E.2d 266, 268 (Mass. 1956).

When a party has a contractual obligation to deliver readily obtainable goods, courts have invalidated a provision for liquidated damages on the ground that the injury which a breach would cause the buyer could be easily calculated by deducting the contract price from the market price. 5 Corbin, Contracts $\$ 1064$ (1951). Similarly, it may be contended that if the contractor does not perform at all, the loss caused to the promisee would be the difference between the price charged by the contractor and the price to be paid a substitute contractor. However, to the extent that a substitute contractor is not readily obtainable and the subsequent delay in completing performance causes lost profits, the situations are not completely analogous; accordingly, a liquidated damage provision covering a contractor's total failure of performance might be sustained. Cf. note 69 supra and accompanying text.

73. See 5 Corbin, Contracts $\$ 1066$ (1951).

74. While a provision for an alternate means of payment could not be considered as a waiver of any legal remedies on the contract, performance of such alternative earns the party a complete discharge. Satisfaction of a clause for liquidated damages, on the other hand, is not one of two performances a party may elect but one of two remedies available to the party who has performed. 5 Corbin, Contracts $\$ 1070$ (1951); 3 Wrutston, Contracts $\$ 781$ (rev. ed. 1936).

75. 5 CoRBIn, Contracts $\$ 1065$ (1951). Only the legal rate of interest may be included if the higher sum payable on default is not to be deemed a penalty. Courts are wary of the argument that the higher amount payable is the price bargained for by the parties 
Similarly, in the case of the letter of credit opened for the $\mathrm{CCC}^{76}$ a penalty element might be present if the amount of the instrument was greater than the fair market value of the strategic materials which the grain exporter was obligated to deliver. When a letter of credit is a source of compensation for a surety, ${ }^{77}$ the device is not susceptible to attack as a penalty, since the surety is enabled to collect only the amount which the customer owes him as reimbursement for payment under the bond.

\section{CONCLUSION}

As a method of insuring compensation for a breach of a contractual duty, the commercial letter of credit differs markedly from other security devices traditionally employed by contracting parties: the promisee is entitled to payment merely upon alleging that the promisor has not rendered the bargained-for performance. Thus, the instrument will be utilized to secure the fulfillment of a contractual obligation only when the promisor has complete confidence in the good faith of his promisee. The very fact that the beneficiary of the "new" letter of credit enjoys such unrestricted powers of collection accents troublesome penalty questions. It would seem that the parties can mitigate the danger that the mechanism will be deemed penal by providing a maximum amount of recovery for each of the various possible kinds of contractual breaches. Thus, if the alleged breach were one day's delay in completion of performance, the beneficiary would not be given the freedom to collect the same sum which he might recover in the event of a year's delay in completing performance or a total failure of performance. If the maximum amounts specified were reasonable estimates of the harm flowing from the particular breach, and if the actual injury which would be caused by the breach appeared difficult to ascertain, the letter of credit device would come much closer to resembling a valid liquidated damages provision. In addition, there is some chance that these variations will be labeled an ultra vires guaranty. Although courts should not hesitate to vitiate letters of credit which are disguised penalties, they should be reluctant to brand other transactions ultra vires. The growth of the letter of credit has been due in large measure to the willingness of courts to align case law with progressive commercial practice. Accordingly, conceptual difficulties involving the power of a bank to issue a "new" letter of credit should yield to the dictates of modern business needs.

and the lower amount represents a discount for prompt payment. To determine whether the higher amount is in fact a penalty notwithstanding this contention, the courts will consider the fair market value of the goods sold. Ibid.

76. See notes $18-19$ supra and accompanying text.

77. See notes 20-22 supra and accompanying text. 